\title{
Anti-Müllerian Hormone and Its Clinical Use in Pediatrics with Special Emphasis on Disorders of Sex Development
}

\author{
Marie Lindhardt Johansen, ${ }^{1}$ Casper P. Hagen, ${ }^{1}$ \\ Trine Holm Johannsen, ${ }_{1}^{1}$ Katharina M. Main, ${ }^{1}$ Jean-Yves Picard, ${ }^{2}$ Anne Jørgensen, ${ }^{1}$ \\ Ewa Rajpert-De Meyts, ${ }^{1}$ and Anders Juul ${ }^{1}$ \\ ${ }^{1}$ Department of Growth and Reproduction, GR, 5064 Rigshospitalet, Faculty of Medical and Health Sciences, University of Copenhagen, \\ Blegdamsvej 9, 2100 Copenhagen, Denmark \\ ${ }^{2}$ INSERM U782 Research Unit and Paris Sud University, 92140 Clamart, France
}

Correspondence should be addressed to Anders Juul; anders.juul@regionh.dk

Received 15 May 2013; Accepted 20 October 2013

Academic Editor: Petra Stute

Copyright (C) 2013 Marie Lindhardt Johansen et al. This is an open access article distributed under the Creative Commons Attribution License, which permits unrestricted use, distribution, and reproduction in any medium, provided the original work is properly cited.

\begin{abstract}
Using measurements of circulating anti-Müllerian hormone (AMH) in diagnosing and managing reproductive disorders in pediatric patients requires thorough knowledge on normative values according to age and gender. We provide age- and sex-specific reference ranges for the Immunotech assay and conversion factors for the DSL and Generation II assays. With this tool in hand, the pediatrician can use serum concentrations of AMH when determining the presence of testicular tissue in patients with bilaterally absent testes or more severe Disorders of Sex Development (DSD). Furthermore, AMH can be used as a marker of premature ovarian insufficiency (POI) in both Turner Syndrome patients and in girls with cancer after treatment with alkylating gonadotoxic agents. Lastly, its usefulness has been proposed in the diagnosis of polycystic ovarian syndrome (PCOS) and ovarian granulosa cell tumors and in the evaluation of patients with hypogonadotropic hypogonadism.
\end{abstract}

\section{Introduction}

Anti-Müllerian hormone (AMH), also known as Müllerian inhibiting substance, is essential for the involution of the Müllerian ducts (the anlagen of the internal female genitalia) in the male fetus [1-3]. Male sex differentiation is completely dependent on the normal development of testes that produce ample amounts of testosterone and AMH. The two hormones, produced by Leydig cells and Sertoli cells, respectively, represent two distinct pathways in male sex differentiation. Testosterone is responsible for the differentiation of the Wolffian ducts, the urogenital sinus, and the external genitalia. By contrast, AMH does not have any known function in female fetal organogenesis.

Determination of the serum AMH concentration is used in various ways in clinical pediatrics to determine the presence of testicular tissue in patients with cryptorchidism, suspected anorchia, or more severe Disorders of Sex Development (DSD). Also, AMH may be used as a marker of premature ovarian insufficiency (POI). It has been proposed as a marker in polycystic ovarian syndrome (PCOS) [4], as a tumor load marker in ovarian granulosa cell tumors [5] and, lastly, in hypogonadotropic hypogonadism [6].

This paper gives a brief overview of the physiology of $\mathrm{AMH}$ and seeks to give clinicians a tool when interpreting results from different assays. The aim is to simplify the use of $\mathrm{AMH}$ in clinical pediatrics.

\section{Expression and Regulation of AMH}

$\mathrm{AMH}$ is produced by Sertoli and granulosa cells in the male and female, respectively. AMH is a member of the TGF- $\beta$ family and is encoded by the $A M H$ gene, which contains 5 exons [7] and is located on chromosome 19 p13.3 [8] (see 

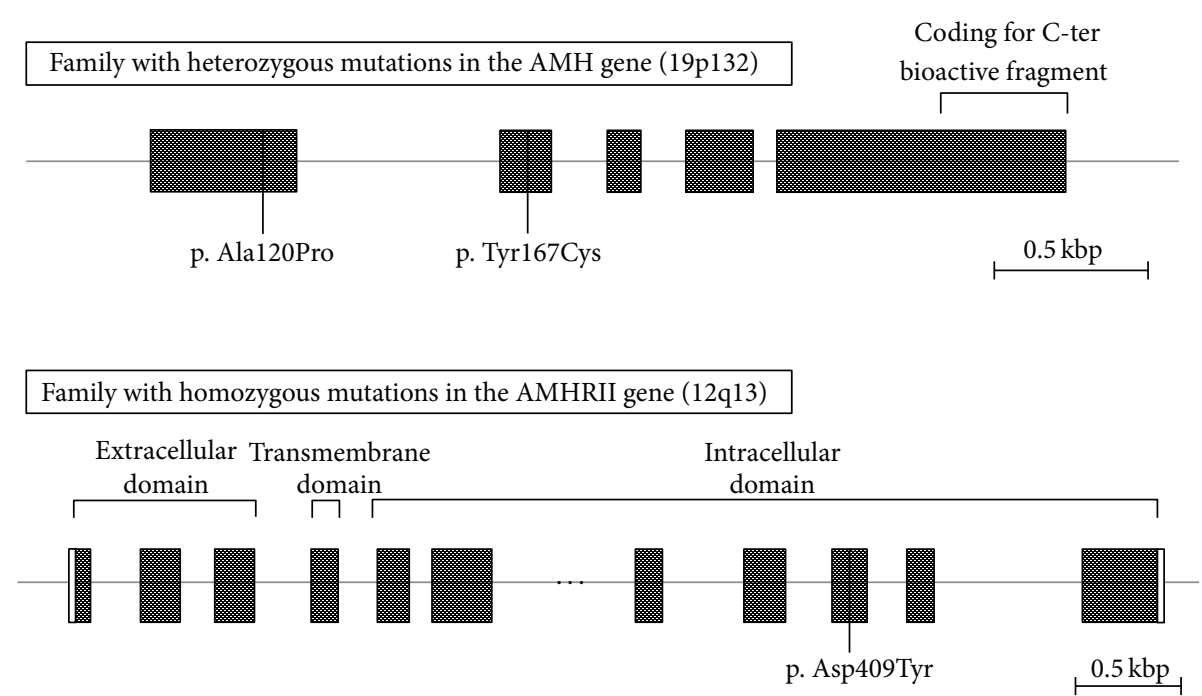

Figure 1: Mutations of the $A M H$ gene (Case 1) and the $A M H-R I I$ gene (Case 2) in two families with boys presenting with PMDS. Two missense mutations in exons 1 and 2 (substitution of alanine by proline and of tyrosine by cysteine, resp.) were found in the $A M H$ gene in two brothers presenting with AMH-negative PMDS. A homozygous missense mutation in exon 9 (substitution of aspartic acid by tyrosine) in the AMH-RII gene was found in two brothers presenting with AMH-positive PMDS.

Figure 1 for an iconography of the gene). The hormone binds to the specific AMH type II receptor (AMH-RII), which is encoded by a gene found on chromosome 12 p13 (see Figure 1 for an iconography of the gene) [9]. The receptor is a single transmembrane protein with serine-threonine kinase activity, and it is present on the cell membrane of target organs (including the mesenchymal cells of the Müllerian ducts, the granulosa cells of the ovary, and the Sertoli and Leydig cells of the testis) [10].

Several genes play a role in the regulation of $\mathrm{AMH}$ production from Sertoli cells. The SRY gene, for example, is important for the activation of SOX9, which together with steroidogenic factor 1 (SF1) and DAX1 directly stimulates the expression of $A M H$ in the fetal testes $[14,15]$.

\section{Male and Female Serum AMH Reference Ranges}

We have previously reported serum AMH reference ranges for males and females throughout the entire lifespan measured on the Immunotech Coulter assay [11, 12], (Figure 2). At birth, male cord blood has high levels of AMH (mean $148 \mathrm{pmol} / \mathrm{L})$, whereas AMH is undetectable (54\%) or very low (95\% CI: <2-16) in cord sera from female infants. At three months of age, AMH levels increase markedly in both sexes, although the concentrations in females (mean $13 \mathrm{pmol} / \mathrm{L}$ ) remain much lower compared to concentrations in male infants (mean 1047 pmol/L). During childhood, AMH levels are relatively stable in both sexes, boys having approximately 35 times higher levels than girls.

Until pubertal onset, $\mathrm{AMH}$ is consequently a sensitive and specific marker of Sertoli cell activity. With the onset of testosterone synthesis in male puberty, serum AMH levels decline rapidly (mean $50 \mathrm{pmol} / \mathrm{L}$ ), which clearly overlap with the levels seen in healthy females (Figure 2).

\section{The Secretion and Function of AMH}

4.1. AMH in Males. In males, the Sertoli cells begin to secrete AMH during the 7th week of gestation. Figure 3, modified from a series by Jørgensen et al. [16], clearly shows the high expression of $\mathrm{AMH}$ in the fetal testis and furthermore illustrates the reduction of AMH expression in Sertoli cells with increasing age and testosterone production which is also reflected in serum values [12, 17-19]. The adult male testis shows an absence of immunohistochemical staining for $\mathrm{AMH}$. The origin of $\mathrm{AMH}$ in adult male serum is unknown, although testicular origin seems most likely despite the expression pattern seen in Figure 3. This is supported by visible AMH expression in slightly undifferentiated Sertoli cells that are occasionally seen in infertile men, often in Sertoli-cell-only tubules $[20,21]$.

The postnatal surge of AMH, which is seen in Figure 2, is most likely triggered by increasing concentrations of folliclestimulating hormone (FSH) [22-24]. The pubertal decline is most likely caused by androgens after pubertal activation of the androgen receptor in the differentiated Sertoli cell [6, $17,21,25]$. Inhibition probably also happens via the synergy with maturing germ cells rather than only through a direct inhibition of AMH transcription [26-28].

4.2. AMH in Females. In female fetuses, $\mathrm{AMH}$ is not present in ovarian tissues until the 36 th week of gestation [21]. Female $\mathrm{AMH}$ is produced by ovarian granulosa cells of the preantral and early antral follicles [29-31]. The circulating levels of $\mathrm{AMH}$ in adult women reflect the number of remaining primordial follicles [32].

During childhood and adolescence, AMH fluctuations are minimal and each girl maintains her relative level during pubertal transition $[33,34]$. The stable AMH levels during the extensive loss of primordial follicles in childhood are probably balanced on one hand by an increased recruitment 


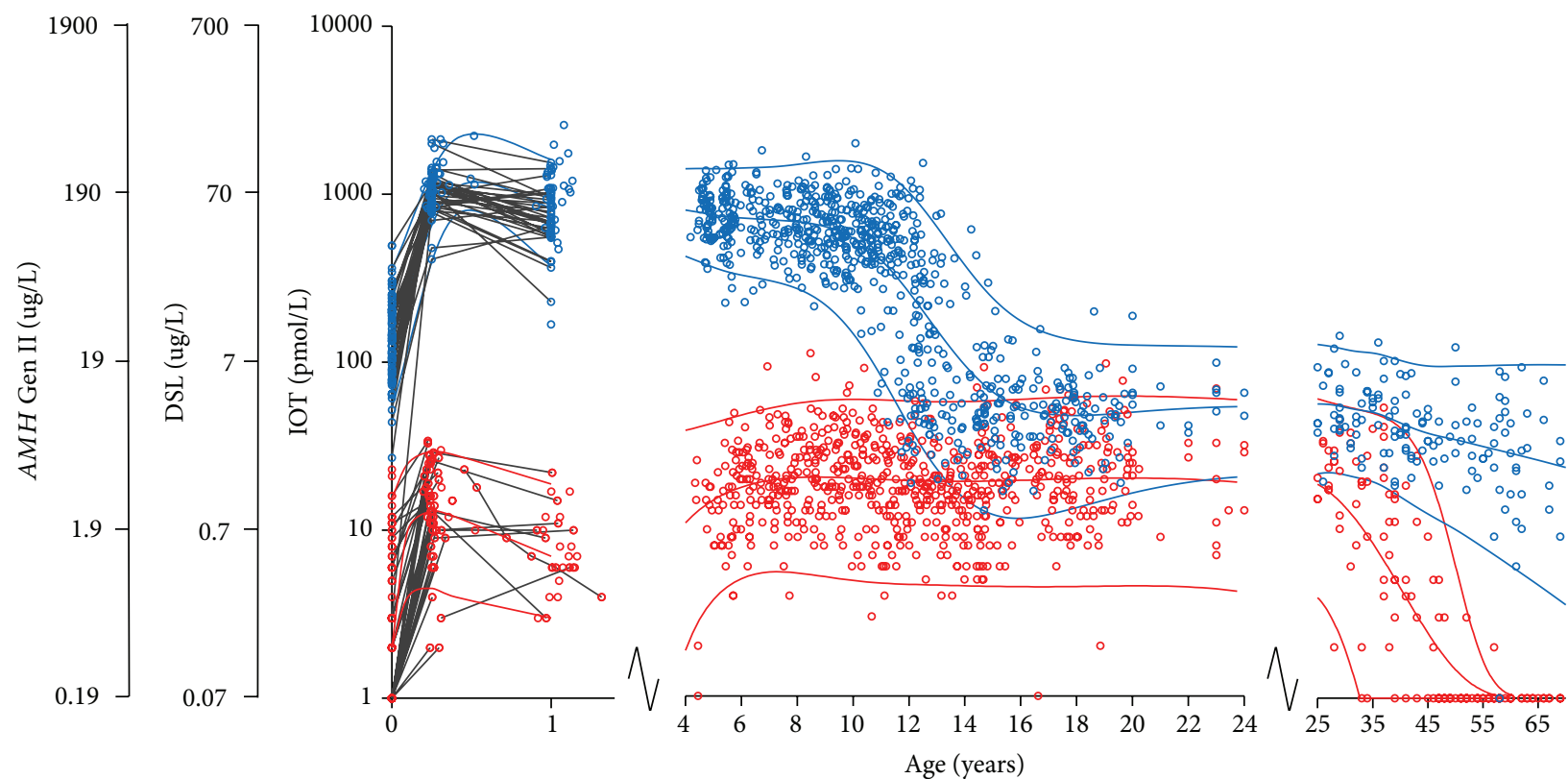

FiguRE 2: Serum AMH in 1953 healthy subjects (926 females and 1027 males) according to age. Females: red circles, males: blue circles. Longitudinal values during infancy are connected with grey lines. The red and blue curves represent the female and male reference ranges, respectively (median, $\pm 2 \mathrm{SD}$ ). The figure was redrawn from our previously published data using Immunotech Coulter enzyme immunometric assay in all subjects [11-13]. Please note the logarithmic $y$-axis. The $y$-axes for the DSL and Gen II assays were created using the following formulas: $\mathrm{AMH}(\mathrm{IOT}) \mathrm{pmol} / \mathrm{L}=2.0 \times \mathrm{AMH}(\mathrm{DSL}) \mathrm{ug} / \mathrm{L} \times 7.14 \mathrm{pmol} / \mathrm{ug}$ and $\mathrm{AMH}(\mathrm{IOT}) \mathrm{pmol} / \mathrm{L}=0.74 \times \mathrm{AMH}(\mathrm{Gen} \mathrm{II}) \mathrm{ug} / \mathrm{L} \times 7.14 \mathrm{pmol} / \mathrm{ug}$.

$10 \mathrm{GW}$

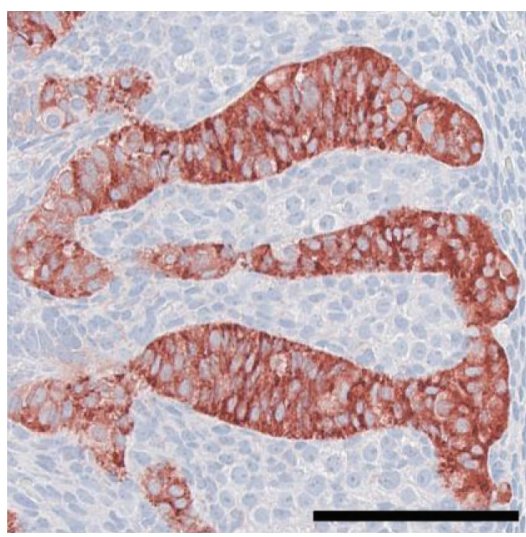

2 months

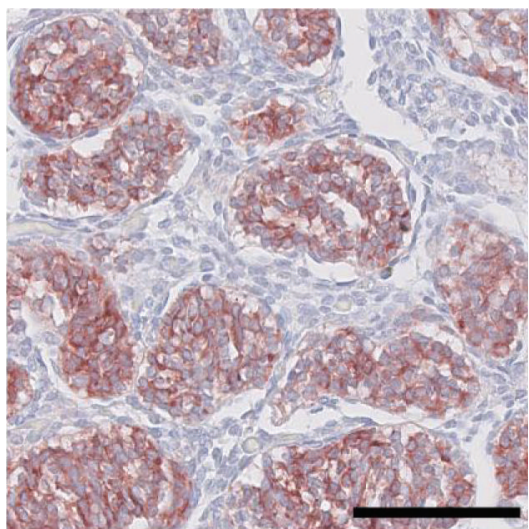

$24 \mathrm{GW}$

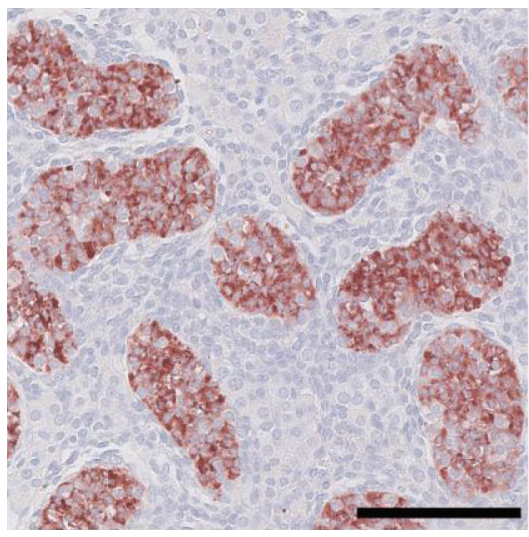

5 years

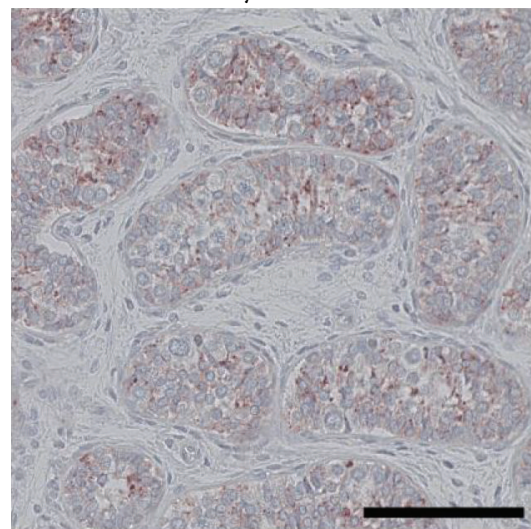

$39 \mathrm{GW}$

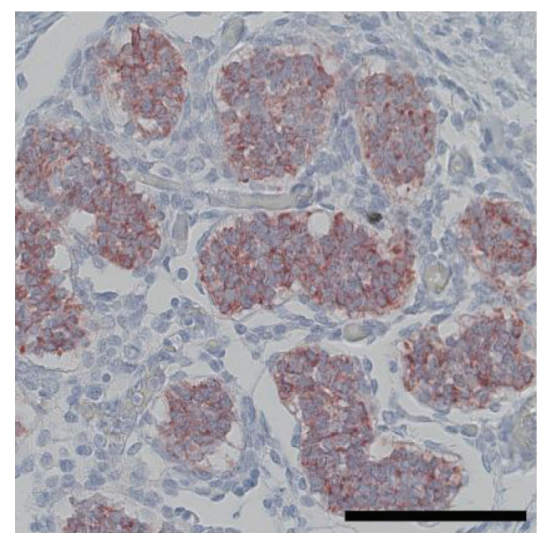

Adult

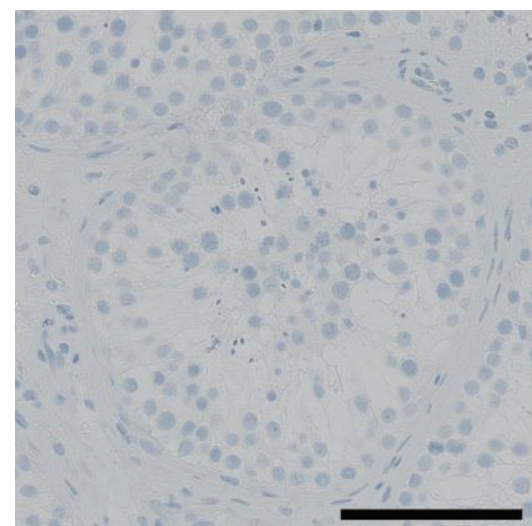

FIGURE 3: Immunohistochemical staining of AMH in testis tissue. GW: gestational week. Scale bar corresponds to $100 \mu \mathrm{m}$. 
rate of primordial follicles during childhood (supplying AMH-producing follicles) and on the other hand by FSHinduced follicle growth at the time of pubertal onset (more follicles grow beyond AMH producing stages) [35].

In female mice, $\mathrm{AMH}$ inhibits primordial follicle recruitment and growth, which probably plays an important role in the maintenance of the follicle pool [36]. AMH furthermore plays a role in the regulation of ovarian steroidogenesis by inhibiting aromatase activity [37] and decreasing intrafollicular estradiol concentrations $[38,39]$.

\section{AMH Assays}

At present, three different AMH assays exist: Diagnostic Systems Lab (DSL by Diagnostic Systems Laboratories, Webster, TX, USA), Immunotech (IOT by Beckman Coulter, Inc., Brea, CA, USA), and the new AMH Generation II assay (Gen II by Beckman Coulter, Inc., Brea, CA, USA). The Gen II assay combines antibodies from the DSL and calibration standards from the IOT $[40,41]$. Until the Gen II assay is ubiquitously implemented, there is a need for assay-specific reference ranges for clinicians to use. Few comparative studies between AMH assays have been performed, but Gen II levels appear to correlate well with both DSL and IOT, although the new assay produces higher values [41-45].

Previously, we reported age- and sex-specific reference ranges [13]; this figure has now been modified to make it assay-specific too, see Figure 2. It is important to note that we have not performed comparative studies with the testing of identical samples on the three different assays. The figure is merely a translation between assays based on current literature.

In Figure 2, the samples have been run with the IOT assay (Immunotech, Marseilles, France) [11, 12]. We use a conversion factor of 2.0 between DSL and IOT, which has previously been suggested and is widely accepted [11, 46, 47]. The units used by IOT and DSL are $\mathrm{pmol} / \mathrm{L}$ and $\mathrm{ug} / \mathrm{L}$, respectively; it is therefore necessary to account for the molecular weight of AMH $(140 \mathrm{kDa}=140 \mathrm{~g} / \mathrm{mol}=7.14 \mathrm{pmol} / \mathrm{ug})$. Consider

$$
\begin{aligned}
\mathrm{AMH}(\mathrm{IOT}) \mathrm{pmol} / \mathrm{L}= & 2.0 \times \mathrm{AMH}(\mathrm{DSL}) \mathrm{ug} / \mathrm{L} \\
& \times 7.14 \mathrm{pmol} / \mathrm{ug} .
\end{aligned}
$$

The $y$-axis for Gen II has been created based on a conversion factor of 0.74 as reached by Li et al. [42], which, to our knowledge, is the only study to date that has run identical samples on both the IOT and Gen II assays. Consider

$$
\begin{aligned}
\mathrm{AMH}(\mathrm{IOT}) \mathrm{pmol} / \mathrm{L}= & 0.74 \times \mathrm{AMH}(\mathrm{Gen} \mathrm{II}) \mathrm{ug} / \mathrm{L} \\
& \times 7.14 \mathrm{pmol} / \mathrm{ug} .
\end{aligned}
$$

The linearity of the relationship at higher values is questioned [42]. The clinical value of AMH measurements during childhood does, however, seem to be preserved despite the uncertainty of high-end values, as the value mostly lies in the distinguishing between low female and high male values in different clinical scenarios.

\section{AMH and Its Clinical Use in Pediatric Patients}

$\mathrm{AMH}$ has a wide clinical potential in pediatrics. Figure 2 provides a clinical tool where a specific $A M H$ value can be interpreted in an age-, sex-, and assay-specific manner.

In the following section, we describe clinical conditions in which detectable versus undetectable AMH measurements are important for diagnosis.

6.1. Determination of the Presence of Testicular Tissue. When a child is born with ambiguous genitalia or bilaterally absent testes (as in Case 1), the determination of the presence or absence of testicular tissue is of utmost importance in terms of treatment and management options. A serum AMH concentration within the normal male reference range is highly indicative of testicular tissue [48-50]. In patients with ambiguous genitalia or cryptorchidism, a low or undetectable AMH concentration is conversely indicative of dysgenetic testicular tissue, anorchia (as seen in Case 1) [49-53] or ovarian tissue [48]. AMH can thus be used to distinguish between anorchia and cryptorchidism in patients without palpable testes.

In patients with ambiguous genitalia, an $\mathrm{AMH}$ value within the normal male reference range indicates intact Sertoli cell function. In the case of patients undergoing surgery, for example, a girl with an ovotestis, AMH can be used as a marker of testicular tissue before and after surgery [54].

The Relevance of Human Chorionic Gonadotropin (hCG) Tests in Patients with Cryptorchidism. hCG testing may not be necessary in determining the absence of testicular tissue; a simple AMH measurement has been suggested to have a higher predictive value than hCG stimulated testosterone levels (hCG stimulation may fail to increase serum testosterone in some patients with abdominal testes [48]), depending on whether or not hCG is given once or repetitively and on the patient's age $[48,50,52]$.

In the case of a patient with undetectable levels of AMH and bilateral cryptorchidism, an hCG test should, however, be performed to asses Leydig cell function and to exclude the rare diagnosis of Persistent Müllerian Duct Syndrome [48, 55]. A lack of increased stimulated testosterone concludes the diagnosis of anorchia (see Case 1), whereas increased concentrations indicate the presence of testicular tissue, and that Persistent Müllerian Duct Syndrome (PMDS) should be considered (see below and Cases 2 and 3) [48].

AMH has furthermore been suggested as a marker used in the management of patients with an isolated microphallus or hypospadias to exclude the possibility of testicular dysgenesis. Few patients, however, have subnormal values indicating testicular dysgenesis as the underlying cause $[50,53,56]$.

Hence, measuring serum AMH is mostly of great clinical value when dealing with patients with ambiguous genitalia or bilateral cryptorchidism.

6.2. Persistent Müllerian Duct Syndrome. Abnormal AMH secretion or action leads to the persistence of the Müllerian 
ducts, that is, uterus, Fallopian tubes, and the upper part of the vagina. This can stem from a mutation in the gene encoding AMH or the AMH type II receptor (AMH-RII), known as PMDS, or it can be a sign of testicular dysgenesis. In the latter case, the phenotype will also be affected by disordered androgen secretion leading to external sexual ambiguity.

Patients with PMDS are referred to as either AMHnegative or -positive (with or without detectable serum concentrations of $\mathrm{AMH}$, resp.), which gives clues to the underlying genetic defect [57]. AMH-negative PMDS is indicative of $A M H$ gene mutations (as in Case 2, gene mutation illustrated in Figure 1), whereas AMH-positive PMDS leads to a suspicion of mutations in the AMH-RII gene (as in Case 3, gene mutation illustrated in Figure 1). In exceptional cases, however, AMH-positive PMDS may be due to a mutation in the $A M H$ gene, which affects $A M H$ bioactivity rather than secretion [58].

A fairly large group of PMDS patients (about $13-15 \%$ as reported by Josso et al. $[57,59])$ remain without a genetic diagnosis, that is, no mutations found in neither the $A M H$ nor the AMH-RII genes.

PMDS patients are phenotypically divided into two groups independent of the underlying genetic defect: patients born with bilateral cryptorchidism and patients born with one descended testis that drags the ipsilateral Fallopian tube into the inguinal canal creating a hernia and a contralateral abdominal testis [57, 60].

6.3. Virilized Females. AMH concentrations also indicate whether the virilization of a girl originates from testicular tissue or a granulosa cell tumor (AMH concentrations in the male reference range) or from adrenal androgens, that is, in the case of congenital adrenal hyperplasia (AMH concentrations in the female reference range). Values within the normal female reference range do not exclude the presence of abnormal gonadal tissue, but undetectable levels exclude the presence of testicular tissue in mildly virilized females $[55,61]$.

In the following section, we will describe clinical conditions in which the relative AMH concentration is important.

\subsection{Low Serum Concentrations of AMH}

Premature Ovarian Insufficiency. In pediatrics, Turner Syndrome patients experiencing accelerated loss of ovarian follicles and cancer patients receiving alkylating gonadotoxic treatment represent the majority of cases of premature ovarian insufficiency (POI). Low or undetectable AMH seems to be an excellent marker of POI in these patients [62-64].

\subsection{Normal Serum Concentrations of AMH}

6.5.1. Hypogonadotropic Hypogonadism. Hypogonadotropic hypogonadism $(\mathrm{HH})$ includes an array of disorders all characterized by low or absent endogenous gonadotropins and consequently low or undetectable sex hormones in pediatric as well as adult patients.
In prepubertal and pubertal males with $\mathrm{HH}$, AMH levels may be subnormal compared to the male reference range [65], whereas postpubertal levels may be high compared to normal male levels [66]. These phenomena could be explained by a lack of FSH stimulus prepubertally and a lack of intratesticular testosterone-mediated downregulation of AMH secretion during and after puberty, respectively $[6,22,23,67]$. Pubertal and postpubertal levels may, however, also be low in patients with more severe $\mathrm{HH}$. This is probably a consequence of the missing FSH stimulus and the subsequently smaller pool of Sertoli cells causing a deficient AMH secretion [68].

$\mathrm{AMH}$ has been proposed as a tool in differentiating between $\mathrm{HH}$ and constitutional pubertal delay but has not yet been proven clinically valuable [65], and some conclude that inhibin B seems to be the better marker of the two [68].

In females, $\mathrm{AMH}$ is low in the reference range due to the partial gonadotropin-dependent regulation of AMH [69]. Traditional endocrine evaluation (gonadotropins, inhibin B, and estradiol) remains as the preferred diagnostic tool for this condition, but AMH appears to be a promising marker of ovarian response in idiopathic $\mathrm{HH}$ patients with induced menstrual cycles [70]. This is important in fertility clinics but not as important in a pediatric setting.

Consequently, AMH is not yet of particular clinical use in pediatrics when suspecting $\mathrm{HH}$ in patients of either sex.

6.5.2. Klinefelter Syndrome (47,XXY). Klinefelter Syndrome (KS) is characterized by small testes, tall stature, and adult hypergonadotropic hypogonadism. Boys with KS have normal AMH concentrations until puberty [71-75]. After the expected pubertal decline, AMH values fall to subnormal concentrations $[71,72,74,76]$. This may be explained by a progressive destruction of the testes seen in patients with 47,XXY [71]. AMH thus seems to be an excellent marker of testicular function in these patients.

\subsection{High Serum Concentrations of AMH}

6.6.1. Granulosa Cell Tumors. Granulosa cell tumors are sex cord tumors that make up $2-5 \%$ of ovarian neoplasms [7780]. Only a few percent, however, are seen prepubertally [81]. In prepubertal girls, granulosa cell tumors may present as precocious puberty [82, 83]. In 1992, AMH was first identified as a granulosa tumor marker [84]. Serum AMH has been shown to be a fairly reliable and specific marker of granulosa cell tumors and their activity [83, 85-90]. In advanced stages, however, the large tumors may gradually lose their AMH expression, rendering AMH as a less reliable marker in these more advanced cases $[5,82]$. One study directly found that tumor size was inversely related to AMH expression [91].

In a clinical pediatric setting, a prepubertal girl presenting with masculine AMH concentrations should be thoroughly examined for the presence of testes (i.e., in the complete type of androgen insensitivity syndrome) or of ovarian pathology (i.e., a granulosa cell tumor). A granulosa cell tumor cannot, however, be excluded in a girl presenting with AMH values within the reference range. 
$\mathrm{AMH}$, together with inhibin, has furthermore been proposed as a residual and relapse tumor marker postsurgically [85].

6.6.2. PCOS. Polycystic ovarian syndrome (PCOS) causes anovulatory infertility and hyperandrogenism along with elevated AMH in premenopausal women [4, 92-94]. AMH has not, however, been proven as a sensitive and specific diagnostic marker of neither PCOS nor of polycystic ovarian morphology [95]. Clear cutoffs do not exist in adolescence $[96,97]$, and several thresholds have been suggested in adults with varying degrees of sensitivity and specificity $[4,95,98$, 99].

Initially following menarche, anovulatory irregular menstrual bleedings are common and often resolve without diagnosis or treatment [100-102]. If an adolescent girl presents with a prolonged period of oligomenorrhea, an elevated serum AMH value may indicate underlying PCOS [92, 103, 104]. AMH is only mildly affected by the menstrual cycle and lowered by oral contraceptives $[46,105,106]$, making it a useful marker for underlying pathology, namely, PCOS, in these patients when a high AMH concentration is found.

In conclusion, AMH is a very useful serum marker of gonadal differentiation and function in pediatric reproductive disorders. This paper has sought to simplify the correlation between the three AMH assays and review the usefulness in diagnosing and managing patients with various pediatric disorders of reproductive endocrinology.

\section{Cases}

7.1. Case 1: Boy Born with Anorchia. This boy was born with a hypoplastic scrotum, no palpable testes in the scrotum or inguinal canal, and an extreme micropenis. Laparoscopy at the age of 4 years was performed, and normal vasa deferentia were found along with normal testicular vessels. However, no testicles were located intra-abdominally. An hCG test at the age of 6 showed testosterone levels below $0.23 \mathrm{nmol} / \mathrm{L}$. This concluded the diagnosis of anorchia, which was furthermore supported by undetectable AMH concentrations. Inhibin B was undetectable at all times. LH was immeasurable and FSH was between 1.37 and $1.63 \mathrm{U} / \mathrm{L}$ prior to puberty induction. Supplemental testosterone treatment was started at the age of 10.5 to induce puberty.

7.2. Case 2: AMH-Negative PMDS Patient. This patient was born at term with a left retractile testis and a right scrotal testis. At one month of age, a right-sided inguinal hernia appeared. The karyotype was that of a normal male, 46 ,XY. Inhibin B concentration was normal $(402 \mathrm{pg} / \mathrm{mL})$, and serum values of $\mathrm{FSH}, \mathrm{LH}$, and testosterone were all within the normal reference range for age. Herniotomy at the age of three months revealed an ovary-looking organ with a Fallopian tube attached bilaterally. Histology showed normal testicular tissue and orchidopexy was performed. Subsequently, laparoscopy was carried out and a uterus was found and removed including bilateral Fallopian tubes. Serum AMH was undetectable and, consequently, the $A M H$ gene was sequenced. As illustrated in Figure 1, this resulted in the findings of two heterozygous missense mutations in exons 1 and 2 of $A M H$, respectively, that is, a substitution of the nonpolar alanine by the nonpolar proline (p.Ala120Pro) in exon 1 and a substitution of the polar tyrosine by the polar cysteine (p.Tyr167Cys) in exon 2.

One and a half year after the birth of this boy, a younger brother was born with a similar phenotype and the same $A M H$ mutations were demonstrated.

7.3. Case 3: AMH-Positive PMDS Patient. This patient was born at term with nonpalpable bilateral cryptorchidism. The karyotype was that of a normal male, 46,XY. An hCG test at the age of 4.5 years resulted in rises in serum testosterone from $<0.23$ to 2.65 (at day 3) and $1.86 \mathrm{nmol} / \mathrm{L}$ (at day 4), respectively. Serum inhibin B was undetectable, and concentrations of FSH and $\mathrm{LH}$ levels were normal. Laparoscopy at the age of two years revealed the presence of intra-abdominal testes, a uterus, and bilateral Fallopian tubes; orchidopexy and hysterectomy were, thus, performed. Serum $\mathrm{AMH}$ was detectable in 5 of 5 samples varying from 17 to $75 \mathrm{pmol} / \mathrm{L}$. Consequently, the $A M H$-RII gene was sequenced. As illustrated in Figure 1, a homozygous missense mutation in $A M H-R I I$ was confirmed, that is, a substitution of the polar aspartic acid by the polar tyrosine (p.Asp490Tyr) in exon 9.

Three years after the birth of this boy, a younger brother was born with a similar phenotype and the same $A M H-R I I$ mutation was demonstrated.

\section{Acknowledgments}

This work was supported by Research grants from the Research committee at Rigshospitalet (Marie Lindhardt Johansen), the Novo Nordisk Foundation (Anders Juul), and the Research committee of the Capital Region (Ewa RajpertDeMeyts).

\section{References}

[1] A. Jost, "Hormonal factors in the sex differentiation of the mammalian foetus," Philosophical transactions of the Royal Society of London. Series B, vol. 259, no. 828, pp. 119-130, 1970.

[2] N. Josso, C. Racine, N. Di Clemente, R. R. Rodolfo Rey, and F. Xavier, "The role of anti-Müllerian hormone in gonadal development," Molecular and Cellular Endocrinology, vol. 145, no. 1-2, pp. 3-7, 1998.

[3] R. A. Rey and R. P. Grinspon, "Normal male sexual differentiation and aetiology of disorders of sex development," Best Practice and Research: Clinical Endocrinology and Metabolism, vol. 25, no. 2, pp. 221-238, 2011.

[4] Y.-H. Lin, W.-C. Chiu, C.-H. Wu, C.-R. Tzeng, C.-S. Hsu, and M.-I. Hsu, "Anti-Müllerian hormone and polycystic ovary syndrome," Fertility and Sterility, vol. 96, no. 1, pp. 230-235, 2011.

[5] S. Jamieson and P. J. Fuller, "Molecular pathogenesis of granulosa cell tumors of the ovary," Endocrine Reviews, vol. 33, no. 1, pp. 109-144, 2012. 
[6] J. Young, R. Rey, B. Couzinet, P. Chanson, N. Josso, and G. Schaison, "Anti-Müllerian hormone in patients with hypogonadotropic hypogonadism," The Journal of Clinical Endocrinology \& Metabolism, vol. 84, no. 8, pp. 2696-2699, 1999.

[7] R. L. Cate, R. J. Mattaliano, and C. Hession, "Isolation of the bovine and human genes for Müllerian inhibiting substance and expression of the human gene in animal cells," Cell, vol. 45, no. 5, pp. 685-698, 1986.

[8] O. Cohen-Haguenauer, J. Y. Picard, and M.-G. Mattei, "Mapping of the gene for anti-Müllerian hormone to the short arm of human chromosome 19," Cytogenetics and Cell Genetics, vol. 44, no. 1, pp. 2-6, 1987.

[9] S. Imbeaud, E. Faure, I. Lamarre et al., "Insensitivity to antiMüllerian hormone due to a mutation in the human antiMüllerian hormone receptor," Nature Genetics, vol. 11, no. 4, pp. 382-388, 1995.

[10] N. Josso and N. Di Clemente, "Transduction pathway of antiMüllerian hormone, a sex-specific member of the TGF- $\beta$ family," Trends in Endocrinology and Metabolism, vol. 14, no. 2, pp. 91-97, 2003.

[11] C. P. Hagen, L. Aksglaede, K. Sørensen et al., "Serum levels of anti-Müllerian hormone as a marker of ovarian function in 926 healthy females from birth to adulthood and in 172 turner syndrome patients," The Journal of Clinical Endocrinology \& Metabolism, vol. 95, no. 11, pp. 5003-5010, 2010.

[12] L. Aksglaede, K. Sørensen, M. Boas et al., "Changes in anti-Müllerian hormone (AMH) throughout the life span: a population-based study of 1027 healthy males from birth (cord blood) to the age of 69 years," The Journal of Clinical Endocrinology \& Metabolism, vol. 95, no. 12, pp. 5357-5364, 2010.

[13] C. P. Hagen, L. Aksglaede, K. Sørensen, A. Mouritsen, and A. Juul, "Clinical use of anti-Müllerian hormone (AMH) determinations in patients with disorders of sex development: importance of sex- and age-specific reference ranges," Pediatric Endocrinology Reviews, vol. 9, pp. 525-528, 2011.

[14] N. A. Arango, R. Lovell-Badge, and R. R. Behringer, "Targeted mutagenesis of the endogenous mouse Mis gene promoter: in vivo definition of genetic pathways of vertebrate sexual development," Cell, vol. 99, no. 4, pp. 409-419, 1999.

[15] A. Swain and R. Lovell-Badge, "Mammalian sex determination: a molecular drama," Genes and Development, vol. 13, no. 7, pp. 755-767, 1999.

[16] A. Jørgensen, J. E. Nielsen, M. B. Jensen, N. Graem, and E. Rajpert-de Meyts, "Analysis of meiosis regulators in human gonads: a sexually dimorphic spatio-temporal expression pattern suggests involvement of DMRT1 in meiotic entry," Molecular Human Reproduction, vol. 18, pp. 523-534, 2012.

[17] R. Rey, I. Lordereau-Richard, J.-C. Carel et al., "Anti-Müllerian hormone and testosterone serum levels are inversely related during normal and precocious pubertal development," The Journal of Clinical Endocrinology \& Metabolism, vol. 77, no. 5, pp. 1220-1226, 1993.

[18] M. M. Lee, P. K. Donahoe, T. Hasegawa et al., "Müllerian inhibiting substance in humans: normal levels from infancy to adulthood," The Journal of Clinical Endocrinology \& Metabolism, vol. 81, no. 2, pp. 571-576, 1996.

[19] M. L. Baker and J. M. Hutson, "Serum levels of Müllerian inhibiting substance in boys throughout puberty and in the first two years of life," The Journal of Clinical Endocrinology \& Metabolism, vol. 76, no. 1, pp. 245-247, 1993.
[20] K. Steger, R. Rey, S. Kliesch, F. Louis, G. Schleicher, and M. Bergmann, "Immunohistochemical detection of immature Sertoli cell markers in testicular tissue of infertile adult men: a preliminary study," International Journal of Andrology, vol. 19, no. 2, pp. 122-128, 1996.

[21] E. Rajpert-de Meyts, N. Jørgensen, N. Græm, J. Müller, R. L. Cate, and N. E. Skakkebæk, "Expression of anti-Müllerian hormone during normal and pathological gonadal development: association with differentiation of Sertoli and granulosa cells," The Journal of Clinical Endocrinology \& Metabolism, vol. 84, no. 10, pp. 3836-3844, 1999.

[22] R. P. Grinspon, N. Loreti, D. Braslavsky et al., "Sertoli cell markers in the diagnosis of paediatric male hypogonadism," Journal of Pediatric Endocrinology and Metabolism, vol. 25, no. 1-2, pp. 3-11, 2012.

[23] R. P. Grinspon and R. A. Rey, "Anti-Müllerian hormone and sertoli cell function in paediatric male hypogonadism," Hormone Research in Paediatrics, vol. 73, no. 2, pp. 81-92, 2010.

[24] C. Lukas-Croisier, C. Lasala, J. Nicaud et al., "Folliclestimulating hormone increases testicular anti-Müllerian hormone $(\mathrm{AMH})$ production through Sertoli cell proliferation and a nonclassical cyclic adenosine $5^{\prime}$-monophosphate-mediated activation of the AMH gene," Molecular Endocrinology, vol. 17, no. 4, pp. 550-561, 2003.

[25] K. Boukari, G. Meduri, S. Brailly-Tabard et al., "Lack of androgen receptor expression in sertoli cells accounts for the absence of anti-Müllerian hormone repression during early human testis development," The Journal of Clinical Endocrinology \& Metabolism, vol. 94, no. 5, pp. 1818-1825, 2009.

[26] B. Jegou, "The Sertoli-germ cell communication network in mammals," International Review of Cytology, vol. 147, pp. 25-96, 1993.

[27] R. Rey, L. Al-Attar, F. Louis et al., "Testicular dysgenesis does not affect expression of anti-Müllerian hormone by sertoli cells in premeiotic seminiferous tubules," American Journal of Pathology, vol. 148, no. 5, pp. 1689-1698, 1996.

[28] R. Rey, "Endocrine, paracrine and cellular regulation of postnatal anti-Müllerian hormone secretion by Sertoli cells," Trends in Endocrinology and Metabolism, vol. 9, no. 7, pp. 271-276, 1998.

[29] J. Bezard, B. Vigier, D. Tran, P. Mauleon, and N. Josso, "AntiMüllerian hormone in sheep follicles," Reproduction Nutrition Developpement, vol. 28, no. 4 B, pp. 1105-1112, 1988.

[30] C. Weenen, J. S. E. Laven, A. R. M. von Bergh et al., "AntiMüllerian hormone expression pattern in the human ovary: potential implications for initial and cyclic follicle recruitment," Molecular Human Reproduction, vol. 10, no. 2, pp. 77-83, 2004.

[31] J. V. Jeppesen, R. A. Anderson, T. W. Kelsey et al., "Which follicles make the most anti-Müllerian hormone in humans? Evidence for an abrupt decline in $\mathrm{AMH}$ production at the time of follicle selection," Molecular Human Reproduction, vol. 19, no. 8, pp. 519-527, 2013.

[32] K. R. Hansen, G. M. Hodnett, N. Knowlton, and L. B. Craig, "Correlation of ovarian reserve tests with histologically determined primordial follicle number," Fertility and Sterility, vol. 95, no. 1, pp. 170-175, 2011.

[33] C. P. Hagen, L. Aksglaede, K. Sørensen et al., "Individual serum levels of anti-Mllerian hormone in healthy girls persist through childhood and adolescence: a longitudinal cohort study," Human Reproduction, vol. 27, no. 3, pp. 861-866, 2012.

[34] H. Lashen, D. B. Dunger, A. Ness, and K. K. Ong, "Peripubertal changes in circulating anti-Müllerian hormone levels in girls," Fertility and Sterility, vol. 99, no. 7, pp. 2071-2075, 2013. 
[35] W. H. B. Wallace and T. W. Kelsey, "Human ovarian reserve from conception to the menopause," PloS ONE, vol. 5, no. 1, Article ID e8772, 2010.

[36] A. La Marca, F. J. Broekmans, A. Volpe, B. C. Fauser, and N. S. MacKlon, "Anti-Müllerian hormone (AMH): what do we still need to know?" Human Reproduction, vol. 24, no. 9, pp. 22642275, 2009.

[37] N. Di Clemente, C. Wilson, E. Faure et al., "Cloning, expression, and alternative splicing of the receptor for anti-Müllerian hormone," Molecular Endocrinology, vol. 8, no. 8, pp. 1006-1020, 1994.

[38] M. P. Grossman, S. T. Nakajima, M. E. Fallat, and Y. Siow, "Müllerian-inhibiting substance inhibits cytochrome P450 aromatase activity in human granulosa lutein cell culture," Fertility and Sterility, vol. 89, no. 5, pp. 1364-1370, 2008.

[39] M. E. Nielsen, I. A. Rasmussen, S. G. Kristensen et al., "In human granulosa cells from small antral follicles, androgen receptor mRNA and androgen levels in follicular fluid correlate with FSH receptor mRNA," Molecular Human Reproduction, vol. 17, no. 1, Article ID gaq073, pp. 63-70, 2011.

[40] S. M. Nelson and A. La Marca, "The journey from the old to the new AMH assay: how to avoid getting lost in the values," Reproductive BioMedicine Online, vol. 23, no. 4, pp. 411-420, 2011.

[41] A. Kumar, B. Kalra, A. Patel, L. McDavid, and W. E. Roudebush, "Development of a second generation anti-Müllerian hormone (AMH) ELISA," Journal of Immunological Methods, vol. 362, no. 1-2, pp. 51-59, 2010.

[42] H. W. Li, E. H. Ng, B. P. Wong, R. A. Anderson, P. C. Ho, and W. S. Yeung, "Correlation between three assay systems for antiMüllerian hormone (AMH) determination," Journal of Assisted Reproduction and Genetics, vol. 29, pp. 1443-1446, 2012.

[43] F. S. Lie, J. A. Visser, C. K. Welt et al., "Serum anti-Müllerian hormone levels in healthy females: a nomogram ranging from infancy to adulthood," The Journal of Clinical Endocrinology \& Metabolism, vol. 97, pp. 4650-4655, 2012.

[44] R. Fleming and S. M. Nelson, "Reproducibility of AMH," Human Reproduction, vol. 27, pp. 3639-3641, 2012.

[45] A. M. Wallace, S. A. Faye, R. Fleming, and S. M. Nelson, "A multicentre evaluation of the new Beckman Coulter antiMüllerian hormone immunoassay (AMH Gen II)," Annals of Clinical Biochemistry, vol. 48, no. 4, pp. 370-373, 2011.

[46] W. J. K. Hehenkamp, C. W. N. Looman, A. P. N. Themmen, F. H. De Jong, E. R. Te Velde, and F. J. M. Broekmans, “Anti-Müllerian hormone levels in the spontaneous menstrual cycle do not show substantial fluctuation," The Journal of Clinical Endocrinology \& Metabolism, vol. 91, no. 10, pp. 4057-4063, 2006.

[47] T. W. Kelsey, P. Wright, S. M. Nelson, R. A. Anderson, and W. H. B. Wallace, "A validated model of serum Anti-Müllerian hormone from conception to menopause," PLoS ONE, vol. 6, no. 7, Article ID e22024, 2011.

[48] M. M. Lee, P. K. Donahoe, B. L. Silverman et al., "Measurements of serum Müllerian inhibiting substance in the evaluation of children with nonpalpable gonads," The New England Journal of Medicine, vol. 336, no. 21, pp. 1480-1486, 1997.

[49] S. Stoppa-Vaucher, A. Djemli, and G. Van Vliet, "Undetectable AMH at 3days of age: a clue to bilateral anorchia," Clinical Biochemistry, vol. 43, no. 16-17, pp. 1373-1374, 2010.

[50] M. Misra, D. T. MacLaughlin, P. K. Donahoe, M. M. Lee, and M. Massachusetts, "Measurement of Müllerian inhibiting substance facilitates management of boys with microphallus and cryptorchidism," The Journal of Clinical Endocrinology \& Metabolism, vol. 87, no. 8, pp. 3598-3602, 2002.

[51] R. P. Grinspon and R. A. Rey, "New perspectives in the diagnosis of pediatric male hypogonadism: the importance of AMH as a sertoli cell marker," Arquivos Brasileiros de Endocrinologia e Metabologia, vol. 55, no. 8, pp. 512-519, 2011.

[52] R. Brauner, M. Neve, S. Allali et al., "Clinical, biological and genetic analysis of anorchia in 26 boys," PLoS ONE, vol. 6, no. 8, Article ID e23292, 2011.

[53] J. Guibourdenche, N. Lucidarme, D. Chevenne et al., "AntiMüllerian hormone levels in serum from human foetuses and children: pattern and clinical interest," Molecular and Cellular Endocrinology, vol. 211, no. 1-2, pp. 55-63, 2003.

[54] M. L. Gustafson, M. M. Lee, L. Asmundson, D. T. MacLaughlin, P. K. Donahoe, and A. Pena, "Müllerian inhibiting substance in the diagnosis and management of intersex and gonadal abnormalities," Journal of Pediatric Surgery, vol. 28, no. 3, pp. 439-444, 1993.

[55] M. M. Lee, M. Misra, P. K. Donahoe, and D. T. MacLaughlin, "MIS/AMH in the assessment of cryptorchidism and intersex conditions," Molecular and Cellular Endocrinology, vol. 211, no. 1-2, pp. 91-98, 2003.

[56] F. H. Pierik, J. A. Deddens, A. Burdorf, S. M. P. F. D. M. KeizerSchrama, F. H. D. Jong, and R. F. A. Weber, "The hypothalamuspituitary-testis axis in boys during the first six months of life: a comparison of cryptorchidism and hypospadias cases with controls," International Journal of Andrology, vol. 32, no. 5, pp. 453-461, 2009.

[57] N. Josso, R. Rey, and J. Y. Picard, “Testicular anti-Müllerian hormone: clinical applications in DSD," Seminars in Reproductive Medicine, vol. 30, pp. 364-373, 2012.

[58] C. Belville, H. Van Vlijmen, C. Ehrenfels et al., "Mutations of the anti-Müllerian hormone gene in patients with persistent Müllerian duct syndrome: biosynthesis, secretion, and processing of the abnormal proteins and analysis using a threedimensional model," Molecular Endocrinology, vol. 18, no. 3, pp. 708-721, 2004.

[59] N. Josso, C. Belville, N. di Clemente, and J.-Y. Picard, "AMH and AMH receptor defects in persistent Müllerian duct syndrome," Human Reproduction Update, vol. 11, no. 4, pp. 351-356, 2005.

[60] D. Guerrier, D. Tran, J. M. Vanderwinden et al., "The persistent Müllerian duct syndrome: a molecular approach," The Journal of Clinical Endocrinology \& Metabolism, vol. 68, no. 1, pp. 46-52, 1989.

[61] M. Misra, D. T. MacLaughlin, P. K. Donahoe, and M. M. Lee, "The role of Müllerian inhibiting substance in the evaluation of phenotypic female patients with mild degrees of virilization," The Journal of Clinical Endocrinology \& Metabolism, vol. 88, no. 2, pp. 787-792, 2003.

[62] C. P. Hagen, K. M. Main, S. Kjaergaard, and A. Juul, "FSH, LH, inhibin $\mathrm{B}$ and estradiol levels in Turner syndrome depend on age and karyotype: longitudinal study of 70 Turner girls with or without spontaneous puberty," Human Reproduction, vol. 25, no. 12, pp. 3134-3141, 2010.

[63] J. A. Visser, A. C. Hokken-Koelega, G. R. Zandwijken, A. Limacher, M. B. Ranke, and C. E. Fluck, "Anti-Müllerian hormone levels in girls and adolescents with Turner syndrome are related to karyotype, pubertal development and growth hormone treatment," Human Reproduction, vol. 28, no. 7, pp. 1899-1907, 2013.

[64] M. F. Brougham, P. M. Crofton, E. J. Johnson, N. Evans, R. A. Anderson, and W. H. Wallace, "Anti-Müllerian hormone 
is a marker of gonadotoxicity in pre- and postpubertal girls treated for cancer: a prospective study," The Journal of Clinical Endocrinology \& Metabolism, vol. 97, pp. 2059-2067, 2012.

[65] L. Adan, P. Lechevalier, A.-C. Couto-Silva et al., "Plasma inhibin $B$ and anti-Müllerian hormone concentrations in boys: discriminating between congenital hypogonadotropic hypogonadism and constitutional pubertal delay," Case Reports and Clinical Practice Review, vol. 16, no. 11, pp. CR511-CR517, 2010.

[66] M. Hero, J. Tommiska, K. Vaaralahti et al., "Circulating antiMüllerian hormone levels in boys decline during early puberty and correlate with inhibin B," Fertility and Sterility, vol. 97, no. 5, pp. 1242-1247, 2012.

[67] J. Young, R. Rey, G. Schaison, and P. Chanson, "Hypogonadotropic hypogonadism as a model of post-natal testicular anti-Müllerian hormone secretion in humans," Molecular and Cellular Endocrinology, vol. 211, no. 1-2, pp. 51-54, 2003.

[68] R. Coutant, E. Biette-Demeneix, C. Bouvattier et al., "Baseline inhibin $\mathrm{B}$ and anti-Müllerian hormone measurements for diagnosis of hypogonadotropic hypogonadism (HH) in boys with delayed puberty," The Journal of Clinical Endocrinology \& Metabolism, vol. 95, no. 12, pp. 5225-5232, 2010.

[69] C. P. Hagen, K. Sorensen, R. A. Anderson, and A. Juul, "Serum levels of anti-Müllerian hormone in early maturing girls before, during, and after suppression with GnRH agonist," Fertility and Sterility, vol. 98, pp. 1326-1330, 2012.

[70] M. Sönmezer, B. Özmen, C. S. Atabekoglu et al., "Serum anti-Müllerian hormone levels correlate with ovarian response in idiopathic hypogonadotropic hypogonadism," Journal of Assisted Reproduction and Genetics, pp. 1-6, 2012.

[71] L. Aksglaede, P. Christiansen, K. Sørensen et al., "Serum concentrations of Anti-Müllerian Hormone (AMH) in 95 patients with Klinefelter syndrome with or without cryptorchidism," Acta Paediatrica, vol. 100, no. 6, pp. 839-845, 2011.

[72] M. G. Bastida, R. A. Rey, I. Bergadá et al., "Establishment of testicular endocrine function impairment during childhood and puberty in boys with Klinefelter syndrome," Clinical Endocrinology, vol. 67, no. 6, pp. 863-870, 2007.

[73] N. Lahlou, I. Fennoy, J.-C. Carel, and M. Roger, "Inhibin B and anti-Müllerian hormone, but not testosterone levels, are normal in infants with nonmosaic klinefelter syndrome," The Journal of Clinical Endocrinology \& Metabolism, vol. 89, no. 4, pp. 18641868, 2004.

[74] N. Pacenza, T. Pasqualini, S. Gottlieb et al., "Clinical presentation of Klinefelter's syndrome: differences according to age," International Journal of Endocrinology, vol. 2012, Article ID 324835, 6 pages, 2012.

[75] R. A. Rey, S. Gottlieb, T. Pasqualini et al., "Are Klinefelter boys hypogonadal?" Acta Paediatrica, vol. 100, no. 6, pp. 830-838, 2011.

[76] A. M. Wikström, T. Raivio, F. Hadziselimovic, S. Wikström, T. Tuuri, and L. Dunkel, "Klinefelter syndrome in adolescence: onset of puberty is associated with accelerated germ cell depletion," The Journal of Clinical Endocrinology \& Metabolism, vol. 89, no. 5, pp. 2263-2270, 2004.

[77] S. Ali, P. Gattuso, A. Howard, M. B. Mosunjac, and M. T. Siddiqui, "Adult granulosa cell tumor of the ovary: fineneedle-aspiration cytology of 10 cases and review of literature," Diagnostic Cytopathology, vol. 36, no. 5, pp. 297-302, 2008.

[78] R. Kanthan, J. L. Senger, and S. Kanthan, "The multifaceted granulosa cell tumours-myths and realities: a review," ISRN Obstetrics and Gynecology, vol. 2012, Article ID 878635, 12 pages, 2012.
[79] N. Colombo, G. Parma, V. Zanagnolo, and A. Insinga, "Management of ovarian stromal cell tumors," Journal of Clinical Oncology, vol. 25, no. 20, pp. 2944-2951, 2007.

[80] S. T. Schumer and S. A. Cannistra, "Granulosa cell tumor of the ovary," Journal of Clinical Oncology, vol. 21, no. 6, pp. 1180-1189, 2003.

[81] A. Ashnagar, S. Alavi, Y. Nilipour, R. Azma, and F. Falahati, "Massive ascites as the only sign of ovarian juvenile granulosa cell tumor in an adolescent: a case report and a review of the literature," Case Reports in Oncological Medicine, vol. 2013, Article ID 386725, 4 pages, 2013.

[82] A. La Marca and A. Volpe, "The anti-Müllerian hormone and ovarian cancer," Human Reproduction Update, vol. 13, no. 3, pp. 265-273, 2007.

[83] L. A. Silverman and S. E. Gitelman, "Immunoreactive inhibin, Müllerian inhibitory substance, and activin as biochemical markers for juvenile granulosa cell tumors," Journal of Pediatrics, vol. 129, no. 6, pp. 918-921, 1996.

[84] M. L. Gustafson, M. M. Lee, R. E. Scully et al., "Müllerian inhibiting substance as a marker for ovarian sex-cord tumor," The New England Journal of Medicine, vol. 326, no. 7, pp. 466471, 1992.

[85] R. A. Rey, C. Lhomme, I. Marcillac et al., "Anti-Müllerian hormone as a serum marker of granulosa cell tumors of the ovary: comparative study with serum $\alpha$-inhibin and estradiol," American Journal of Obstetrics and Gynecology, vol. 174, no. 3, pp. 958-965, 1996.

[86] A. H. Lane, M. M. Lee, A. F. Fuller Jr., D. J. Kehas, P. K. Donahoe, and D. T. MacLaughlin, "Diagnostic utility of Müllerian inhibiting substance determination in patients with primary and recurrent granulosa cell tumors," Gynecologic Oncology, vol. 73, no. 1, pp. 51-55, 1999.

[87] W.-Q. Long, V. Ranchin, P. Pautier et al., "Detection of minimal levels of serum anti-Müllerian hormone during follow-up of patients with ovarian granulosa cell tumor by means of a highly sensitive enzyme-linked immunosorbent assay," The Journal of Clinical Endocrinology \& Metabolism, vol. 85, no. 2, pp. 540$544,2000$.

[88] H. L. Chang, N. Pahlavan, E. F. Halpern, and D. T. MacLaughlin, "Serum Müllerian inhibiting substance/anti-Müllerian Hormone levels in patients with adult granulosa cell tumors directly correlate with aggregate tumor mass as determined by pathology or radiology," Gynecologic Oncology, vol. 114, no. 1, pp. 57-60, 2009.

[89] L. E. Puls, J. Hamous, M. S. Morrow, A. Schneyer, D. T. MacLaughlin, and V. D. Castracane, "Recurrent ovarian sex cord tumor with annular tubules: tumor marker and chemotherapy experience," Gynecologic Oncology, vol. 54, no. 3, pp. 396-401, 1994.

[90] R. Rey, J.-C. Sabourin, M. Venara et al., "Anti-Müllerian hormone is a specific marker of sertoli- and granulosa-cell origin in gonadal tumors," Human Pathology, vol. 31, no. 10, pp. 1202$1208,2000$.

[91] M. Anttonen, L. Unkila-Kallio, A. Leminen, R. Butzow, and M. Heikinheimo, "High GATA-4 expression associates with aggressive behavior, whereas low anti-Müllerian hormone expression associates with growth potential of ovarian granulosa cell tumors," The Journal of Clinical Endocrinology \& Metabolism, vol. 90, no. 12, pp. 6529-6535, 2005.

[92] T. Sir-Petermann, E. Codner, M. Maliqueo et al., "Increased anti-Müllerian hormone serum concentrations in prepubertal daughters of women with polycystic ovary syndrome," The 
Journal of Clinical Endocrinology \& Metabolism, vol. 91, no. 8, pp. 3105-3109, 2006.

[93] P. Pigny, E. Merlen, Y. Robert et al., "Elevated serum level of anti-Müllerian hormone in patients with polycystic ovary syndrome: relationship to the ovarian follicle excess and to the follicular arrest," The Journal of Clinical Endocrinology \& Metabolism, vol. 88, no. 12, pp. 5957-5962, 2003.

[94] J. S. E. Laven, A. G. M. G. J. Mulders, J. A. Visser, A. P. Themmen, F. H. De Jong, and B. C. J. M. Fauser, "AntiMüllerian hormone serum concentrations in normoovulatory and anovulatory women of reproductive age," The Journal of Clinical Endocrinology \& Metabolism, vol. 89, no. 1, pp. 318-323, 2004.

[95] D. Dewailly, H. Gronier, E. Poncelet et al., "Diagnosis of polycystic ovary syndrome (PCOS): revisiting the threshold values of follicle count on ultrasound and of the serum AMH level for the definition of polycystic ovaries," Human Reproduction, vol. 26, no. 11, pp. 3123-3129, 2011.

[96] R. Hart, D. A. Doherty, R. J. Norman et al., "Serum antiMüllerian hormone (AMH) levels are elevated in adolescent girls with polycystic ovaries and the polycystic ovarian syndrome (PCOS)," Fertility and Sterility, vol. 94, no. 3, pp. 1118$1121,2010$.

[97] L. Li, X. Chen, Y. Mo, Y. Chen, M. Wenig, and D. Yang, "Elevated serum anti-Müllerian hormone in adolescent and young adult Chinese patients with polycystic ovary syndrome," Wiener Klinische Wochenschrift, vol. 122, no. 17-18, pp. 519-524, 2010.

[98] P. Pigny, S. Jonard, Y. Robert, and D. Dewailly, "Serum antiMüllerian hormone as a surrogate for antral follicle count for definition of the polycystic ovary syndrome," The Journal of Clinical Endocrinology \& Metabolism, vol. 91, no. 3, pp. 941-945, 2006.

[99] L. Casadei, A. Madrigale, F. Puca et al., "The role of serum anti-Müllerian hormone (AMH) in the hormonal diagnosis of polycystic ovary syndrome," Gynecological Endocrinology, vol. 29, no. 6, pp. 545-550, 2013.

[100] D. Apter, L. Viinikka, and R. Vihko, "Hormonal pattern of adolescent menstrual cycles," The Journal of Clinical Endocrinology \& Metabolism, vol. 47, no. 5, pp. 944-954, 1978.

[101] F. Rigon, V. De Sanctis, S. Bernasconi et al., "Menstrual pattern and menstrual disorders among adolescents: an update of the Italian data," Italian Journal of Pediatrics, vol. 38, p. 38, 2012.

[102] R. F. Vollman, "The menstrual cycle," Major Problems in Obstetrics and Gynecology, vol. 7, pp. 1-193, 1977.

[103] M. Pawelczak, L. Kenigsberg, S. Milla, Y. H. Liu, and B. Shah, "Elevated serum anti-Müllerian hormone in adolescents with polycystic ovary syndrome: relationship to ultrasound features," Journal of Pediatric Endocrinology and Metabolism, vol. 25, pp. 983-989, 2012.

[104] A. S. Park, M. A. Lawson, S. S. Chuan et al., "Serum antiMüllerian hormone concentrations are elevated in oligomenorrheic girls without evidence of hyperandrogenism," The Journal of Clinical Endocrinology \& Metabolism, vol. 95, no. 4, pp. 17861792, 2010.

[105] J. G. Bentzen, J. L. Forman, A. Pinborg et al., "Ovarian reserve parameters: a comparison between users and non-users of hormonal contraception," Reproductive BioMedicine Online, vol. 25, pp. 612-619, 2012.
[106] E. Arbo, D. V. Vetori, M. F. Jimenez, F. M. Freitas, N. Lemos, and J. S. Cunha-Filho, "Serum anti-Müllerian hormone levels and follicular cohort characteristics after pituitary suppression in the late luteal phase with oral contraceptive pills," Human Reproduction, vol. 22, no. 12, pp. 3192-3196, 2007. 


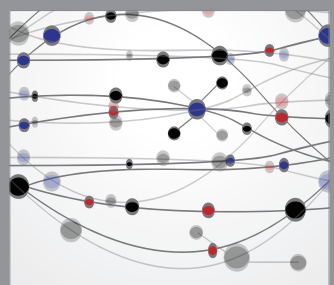

The Scientific World Journal
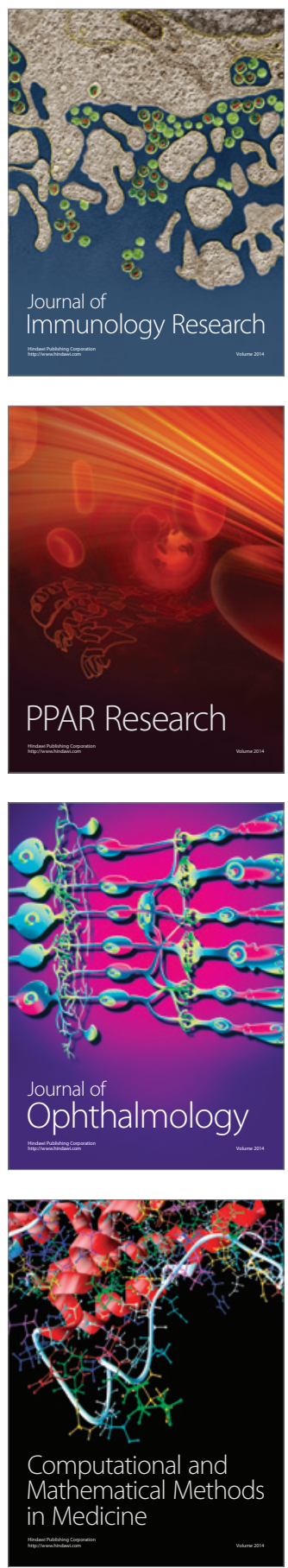

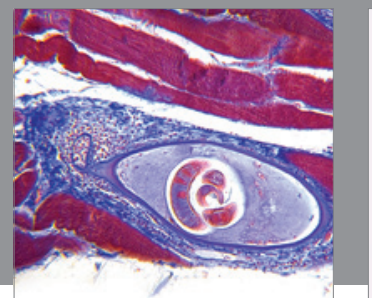

Gastroenterology

Research and Practice
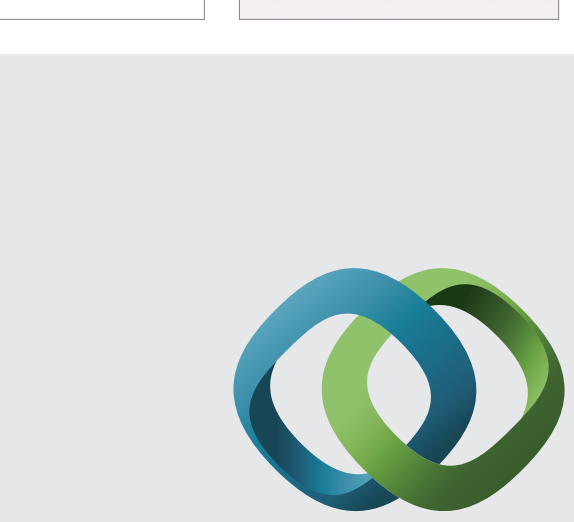

\section{Hindawi}

Submit your manuscripts at

http://www.hindawi.com
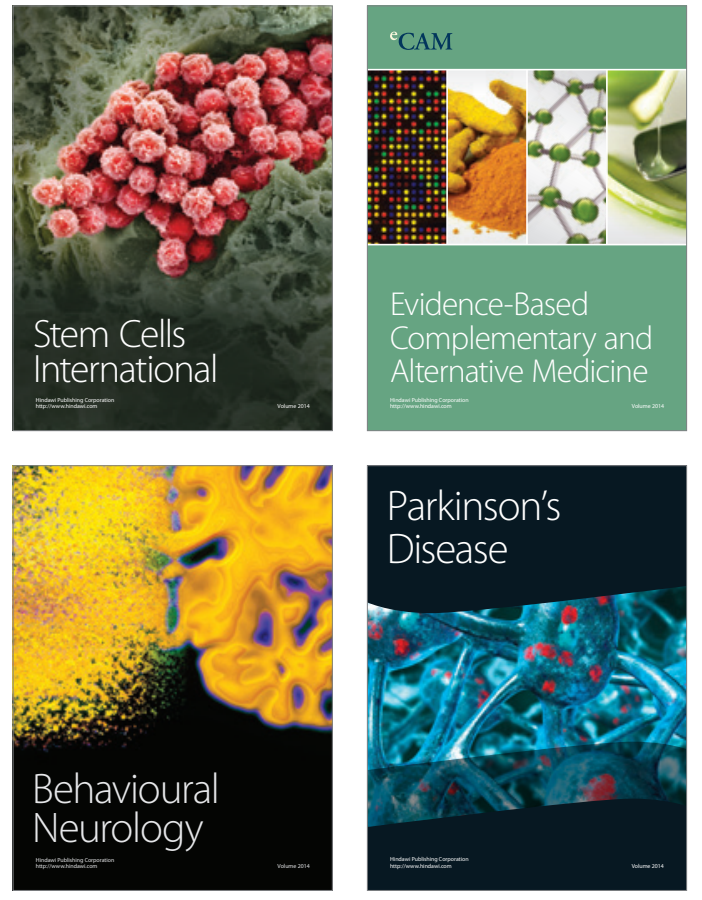
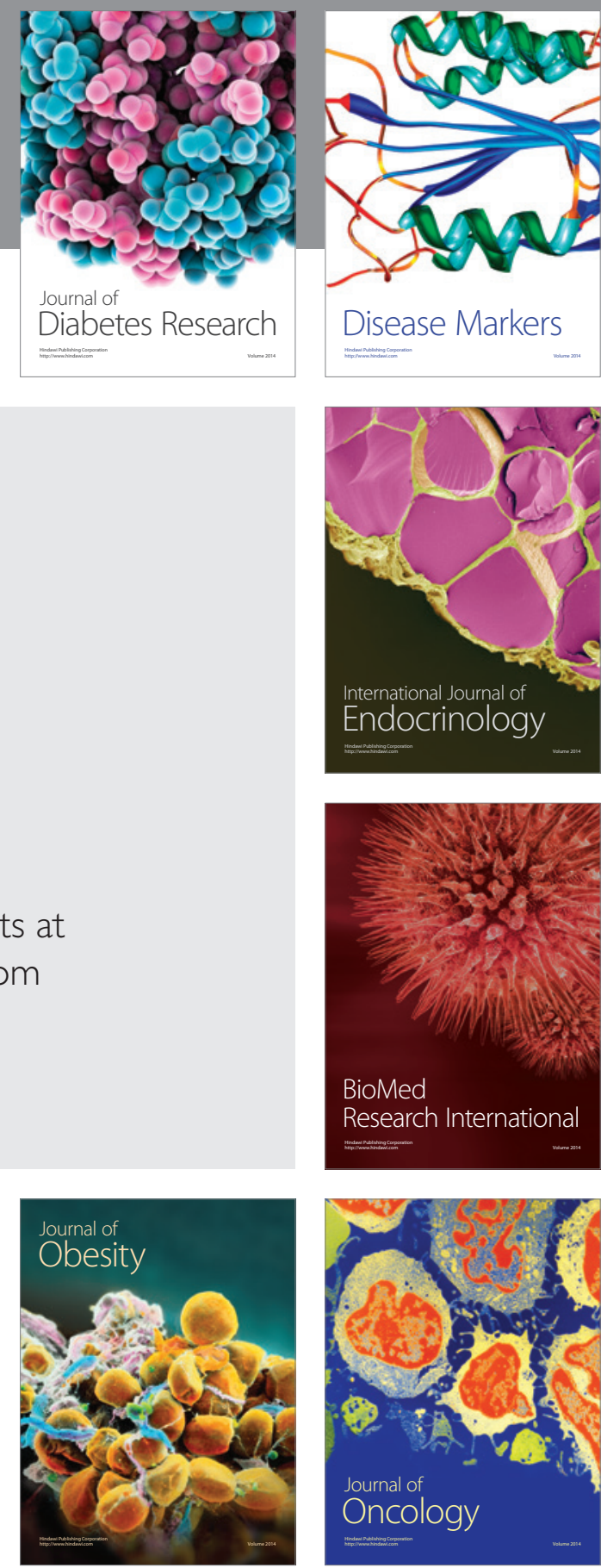

Disease Markers
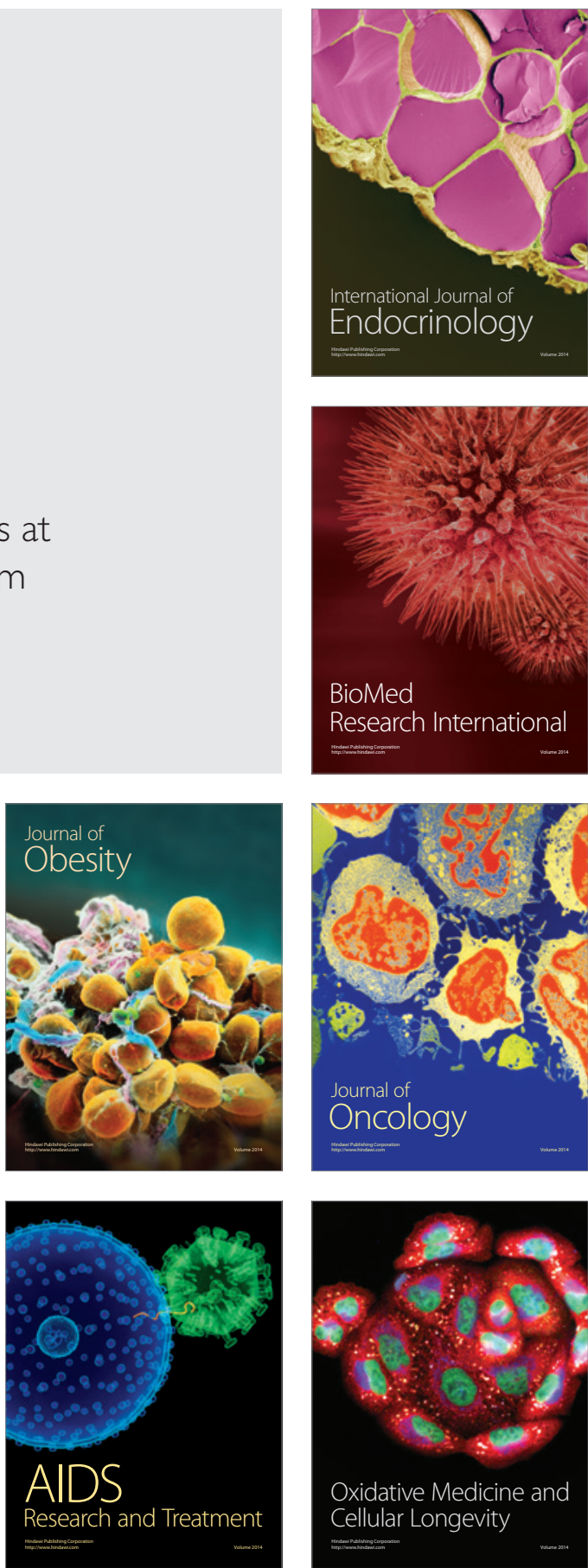